\title{
THE UNITED STATES AND THE LAW OF THE SEA AFTER UNCLOS III
}

\author{
JAMES L. MALONE* \\ I \\ INTRODUCTION
}

The United States did not approve the recently completed Law of the Sea Convention, nor will we sign it, because of our objections to the Treaty's provisions on deep seabed mining. Our rejection of the final Convention was an unfortunate end to our decade-long effort to produce a comprehensive oceans agreement.

II

\section{The United States Decision Not to Sign the Convention}

The United States has always recognized the critical importance of the world's oceans to mankind as a potentially enormous source of food, fuel, and minerals and as a vehicle for communication, navigation, and scientific learning. The United States has been a leader in the development of international oceans law. For the past decade, the United States worked diligently with other nations to develop a Law of the Sea Treaty. Throughout these negotiations, it has been our national policy to defend the freedom of navigation and communication, promote the rights of resource exploration and development, and advance obligations to protect the marine environment.

Shortly after assuming office, President Reagan suspended United States participation in the Tenth Session of the Third U.N. Conference on Law of the Sea (UNCLOS III) and ordered a high-level interagency review of our national oceans policy. This exhaustive, year-long review concluded that the draft Convention's nonseabed provisions regarding navigation, overflight, the continental shelf, marine research, and the environment generally reflected customary international law and were acceptable to the United States. The deep seabed mining provisions of the Draft Convention text were, however, unacceptable and clearly contrary to vital U.S. interests. In addition, the Convention would create other undesirable precedents, such as the mandatory transfer of technology and distribution of funds to national liberation movements.

On January 29, 1982, after reviewing the interagency report, the President announced that the United States would return to the negotiations and would continue to negotiate with other nations to reach agreement on an acceptable Law

\footnotetext{
Copyright $(1983$ by Law and Contemporary Problems

* Assistant Secretary of State for Oceans and International Environment and Scientific Affairs: Special Representative of the President for Law of the Sea; Chairman, United States Delegation to UNCLOS III.
} 
of the Sea Convention. The President emphasized our strong commitment to multilateral negotiations, but he also made it clear that final U.S. acceptance of the LOS Convention was premised on the satisfaction of six key objectives in the Convention's deep seabed provisions. To this end, the President instructed the U.S. delegation to negotiate a treaty that:

would not deter development of any deep seabed mineral resources to meet national and world demand;

would assure national access to these resources by current and future qualified entities to enhance U.S. security of supply, to avoid monopolization of the resources by the operating arm of the International Seabed Authority, and to promote the economic development of the resources;

would provide a decision-making role in the deep seabed regime that fairly reflected and effectively protected the political and economic interests and financial contributions of participating states;

would not allow for amendments to come into force without approval of the participating states, including in our case the advice and consent of the Senate:

would not set other undesirable precedents for international organizations; and

would be likely to receive the advice and consent of the Senate. In this regard, the Convention should not contain provisions for the mandatory transfer of private technology and participation by, and funding for, national liberation movements. ${ }^{1}$

Throughout the negotiations, a principal goal of the United States was the development of an international regime that would permit commercial exploration and development of deep seabed minerals under reasonable terms and conditions. The six objectives announced by the President satisfied U.S. interests and would have benefited all nations by creating a sound legal foundation for the development of seabed minerals.

The U.S. delegation returned to UNCLOS III in New York fully prepared to work and negotiate with other nations in order to develop mutually acceptable solutions to the difficult problems facing the Conference. Unfortunately, there was very little actual negotiation, and after two months of intensive efforts by the U.S. negotiating team, it became clear that the President's objectives would not be fulfilled. Not surprisingly, the Conference ultimately adopted the Law of the Sea Convention over U.S. objections in April of 1982.

As a consequence, on July 9, 1982, the President declared that the United States would not sign the LOS Convention and that further U.S. participation in the remaining conference process would be at the technical level limited to those provisions that serve U.S. interests. In his statement, President Reagan explained that the following problems remained with the Convention adopted by the Conference:

Provisions that would actually deter future development of deep seabed mineral resources, when such development should serve the interest of all countries;

A decision-making process that would not give the United States or others a role that fairly reflects and protects their interests;

Provisions that would allow amendments to enter into force for the United States without its approval; this is clearly incompatible with the U.S. approach to such treaties:

Stipulations relating to mandatory transfer of private technology and the possibility of national liberation movements sharing in benefits; and

1. Statement by the President, 18 Weekly Comp. Pres. Dex: 94 (Jan. 29. 1982). 
The absence of assured access for future qualified deep seabed miners to promote the development of these resources. ${ }^{2}$

It should be noted that U.S. companies support the President's decision not to sign the Convention. They agree with the President's conclusion that the Treaty would jeopardize private access to seabed resources and establish adverse precedents in necessary conflict with the interests of industrialized nations.

\section{A. Why the Convention Cannot be Changed by the Preparatory Commission}

The deep seabed provisions of the Convention establish an international bureaucracy called the Preparatory Commission (PrepCom). The Preparatory Commission will be responsible for developing the rules and regulations which will govern deep seabed mining. The Preparatory Commission convened in March 1983 to begin the process of implementing the Treaty's deep seabed mining provisions. Many critics of the Administration's decision not to sign the Convention have suggested that our decision not to sign the Convention was premature and that the Preparatory Commission can alleviate the vast majority of our objections and concerns. This is not true.

During the Conference, the United States consistently objected to those specific articles of the Convention which were contrary to our national interests. Despite prolonged efforts at negotiations, however, the United States was unable to achieve any substantive changes in the Covention text during the Conference due in large part to the inflexibility of the Conference management. The Preparatory Commission is bound to the language of the Convention and cannot change the Convention text. Therefore, it cannot formulate rules and regulations which will in any way overcome the U.S. objections to the deep seabed portions of the Convention.

Moreover, U.S. participation in the Preparatory Commission could not "clarify" ambiguities in the Treaty nor serve any meaningful purpose. In fact, L.S. participation in the PrepCom might inferentially suggest to other nations that U.S. objections to the Treaty are merely rhetoric and that the United States intends to sign the Convention eventually. The United States will not sign the Convention and any inference, impression, or perception to the contrary would hinder our efficacy in developing alternative deep seabed regimes, thereby possibly destroying the legitimate expectations of U.S. companies and our allies

\section{B. The New International Economic Order}

Proponents of the LOS Convention frequently espouse the concept of the New International Economic Order (NIEO) which in essence advocates redistribution of the world's economic wealth through organizations such as the International Seabed Authority. Indeed, high-level LOS officials are already proclaiming that the principle of the NIEO, as incorporated in the LOS Treaty, can be applied in other areas such as the Antarctic and outer space. The United States is deeply concerned about the grave dangers of legitimizing this socialist concept by signing the LOS Treaty.

2. Statement by the President, 18 Whikly Comp. Pres. Dex: $887.887-88$ (July 9. 198'?). 
Furthermore, the LOS Convention is predicated on the concept that the deep seabed is the "common heritage" of mankind. The "common heritage" is certainly a noble phrase. Unfortunately, the phrase became severely distorted in its meaning during the long LOS negotiations. It became a guise under which the seabed's wealth was to be governed, regulated, and allocated under the false assumption that every nation has an undivided property interest in the deep seabed, and therefore, each is automatically entitled to its proportionate share of the fruits from those whose efforts produce wealth from what would otherwise be economically valueless. The International Seabed Authority would have been given the unprecedented power to redistribute wealth on an international scale.

The United States cannot and will not agree to turn over the management of the resources of the oceans and other largely unexplored frontiers to large, inefficient international bureaucracies. The United States believes that there is an urgent need for international cooperation in defining the rights and obligations of all who wish to participate in the development of such resources. Indeed, it was this very belief in international cooperation which provided the motivation for our participation throughout the UNCLOS III Treaty process. Cooperation, however, implies mutual obligations, and it became disappointingly apparent during negotiations that under the NIEO the developing nations may assert many rights, but they are burdened with very few reciprocal obligations.

The United States has a right to insist upon international mechanisms and policies that are consistent with our free market and democratic principles. It is because of these principles that America obtained her present wealth and high standard of living-it is these same principles which will promote international economic growth and freedom.

\section{Future Course: Deep Seabed Mining}

The LOS Convention discriminates against private investment in deep seabed mining. There will be no investment in seabed mining under the LOS Convention unless governments are willing heavily to subsidize their companies or mining entities. Promoting U.S. flag deep seabed mining under appropriate domestic legislation will be a primary objective of our national oceans policy. The United States and eight other nations seriously interested in commercial seabed mining have completed negotiations on an international agreement creating a deep seabed regime that will encourage investment in marine mining, technological development, exploration, and the production and pricing of mineral resources guided by market forces. This regime will be a minimalist one, which will provide access to and encourage the production of seabed minerals without costly and unnecessary political, legal, and economic restraints.

The American Mining Congress has stated that "a satisfactory investment climate can be created and the basic conditions met by building on the existing Public Law 96-283," 3 the Deep Seabed Hard Mineral Resources Act. ${ }^{4}$ The United States is currently processing applications for ten of the twelve mine sites

3. Law of the Sea: Hearings Before the Subcomm. on Oceanography of the House Comm. on Merchant Marine and 
for which licenses are being sought by existing mining consortia. Despite a few duplicate and conflicting applications filed with other countries, we are in a most favorable position. Conflict resolution procedures have been agreed to by five of the six consortia. Therefore, it is difficult to credit allegations that seabed mining activities will only take place under foreign flags and within the compass of the LOS Treaty.

On September 2, 1982, the United States, Great Britain, West Germany, and France signed an interim agreement which encourages deep seabed mining pioneers to resolve overlaps among license applications and require consultation among the signatories before the issuance of licenses or establishment of reciprocal recognition of mine sites. This agreement demonstrates that the United States can and will continue to cooperate with other nations in the protection and advancement of important oceanic interests.

\section{III}

\section{Future Course: Nonseabed}

The interagency group found that the nonseabed provisions of the LOS Convention were generally consistent with the interests of the United States and were based on customary international law. Therefore, the assertion of our nonseabed interests will not require that we become party to the LOS Convention.

Unimpeded commercial naval and air mobility are essential to our national interests. Some claim that by rejecting the LOS Convention the United States will lose the navigation rights set out in the Convention, rights the United States sought to secure in a comprehensive LOS Convention. According to the argument, if the United States does not accept the seabed mining provisions, the rights set forth in other portions of the Convention are forfeited. This is simply not so. Particularly with respect to navigation rights, the history of the law of the sea has been predominantly a history of customary rules evolving through state practice. In this area the Convention incorporates existing law, which will continue to apply to all states, not because of the Treaty, but because of the customary law underlying the Treaty. This is a fundamental, immutable, and time-honored principle of international law. My government is confident that the United States and our allies have the legal basis to protect our navigational interests outside the Convention.

In addition, those portions of the LOS Convention that are predicated on the creation of new international organizations are clearly contractual in nature and will, therefore, pertain to Treaty parties only. This is the case with the unique and unprecedented provisions on deep seabed exploitation and dispute settlement.

In summary, nonparties to the LOS Convention will continue to have the navigational rights and freedoms recognized in customary international law, including the navigational rights and freedoms recognized in the Convention, whether in the

Fisheries, 97th Cong.. 1st and 2nd Sess. 330 (1981-82) (statement of Conrad G. Welling on behalf of the American Mining Congress).

4. 30 U.S.C. $§ 1401$ (Supp. IV 1980). 
territorial sea, the Exclusive Economic Zone, international straits, or archipelagic waters. This is because the Convention cannot deprive nonparties of their existing rights, either commercial or military. The United States, in particular, will not alter the operations of its maritime forces as a result of its decision not to sign the LOS Treaty.

\section{A. The Exclusive Economic Zone}

Acting upon the recommendation of the interagency Group for Ocean Law and Policy, President Reagan proclaimed the establishment of a 200-mile Exclusive Economic Zone (EEZ) for the United States. The concept of the EEZ is included in the LOS Convention and is generally regarded as having a basis in customary international law. ${ }^{5}$ Typically, the EEZ is recognized as an area beyond and adjacent to the territorial sea within which the coastal state exerts sovereign rights for exploring, exploiting, conserving, and managing the national resources of the seabed, subsoil, and superadjacent waters.

The continental shelf is a major source of petroleum and minerals. Under the 1958 Geneva Convention on the Continental Shelf ${ }^{6}$ and customary international law, a coastal state has sovereign rights over the exploration and exploitation of the living and nonliving resources of its continental shelf. From the underlying theory of the 1958 Convention, a state could consider the resources of its entire adjacent continental margin as an extension of its natural land mass and therefore subject to its jurisdiction and control. The LOS Convention defines for parties the outer edge of the continental margin.

Moreover, the LOS Convention also requires coastal states to make payments to the International Seabed Authority based on a percentage of revenues derived from the exploitation of the resources found within the continental margin beyond 200 miles from the coast. No such obligation exists in customary international law.

Prior to the establishment of the EEZ, the United States already had fishery resource jurisdiction extending 200 nautical miles from the coast, sovereign rights over the resources of the continental shelf, and certain authority beyond the territorial seas relating to pollution control. The establishment of the EEZ does not materially affect our fishery jurisdiction or our continental shelf resource jurisdiction, but it does establish new U.S. jurisdiction over the mineral resources of the ocean floor beyond the continental shelf out to 200 nautical miles. In addition, the EEZ brings within U.S. jurisdiction other economic activities, such as energy production from wind, wave, and tide, as well as marine pollution, marine scientific research including all installations, artificial islands, and structures used for economic purposes.

The establishment of the EEZ demonstrates our intent to protect and promote U.S. interests in developing and conserving those resources to which the United States is entitled under international law. It clearly establishes our rights to the 241.

5. See Continental Shelf (Iunisia v. Libyan Arab Jamahiriya). 1982 I.C.J 4. 74 (Judgnent of Feb.

6. 15 U.S.T. 471. T.I.A.S. No. 5578, 499 U.N.T.S. 311. 
seabed minerals within 200 nautical miles of our coasts. Some of these mineral resources, such as the cobalt-rich crusts on seamounts, have only recently been discovered; but it is likely others will be discovered as exploration of the seabed continues. Furthermore, preservation of the high seas status of the water column of the EEZ provides a valuable precedent that will help limit further encroachment on traditional high seas freedoms in the EEZ's of other countries.

Many nations had feared that the United States, by removing itself from the UNCLOS III process, would reject all jurisdictional claims reflected in the UNCLOS III Convention. This fear was unfounded. By establishing an EEZ, the United States has reassured the international community and restored our leadership in the development of international oceans law. The United States' establishment of an EEZ is a positive demonstration of our continued opposition to certain unacceptable provisions of the UNCLOS III Convention, but at the same time it demonstrates our willingness to conform to those portions of the LOS Convention which reflect customary international law. By shaping the content of our EEZ to permit maximum freedom of the high seas consonant with U.S. resource jurisdiction, we may influence the implementation of the EEZ concept by other states and thus retard further erosion of the freedom of the seas in the 200-mile zones.

\section{B. Fisheries}

Fisheries constitute the world's largest source of protein. The United States will continue to emphasize its national interest in ensuring proper management and conservation of the world's fish stocks and in revitalizing our nation's coastal and distant water fishing industries through economic incentives, reduction of regulatory burdens, and cooperative bilateral and regional arrangements.

The U.S. coastal fisherman's interests are generally protected by the Magnuson Fishery Conservation and Management Act, ${ }^{7}$ and the United States exercises exclusive control and management over all fishery resources, except tuna, within 200 nautical miles of our coast. Approximately ninety-three coastal states have enacted similar unilateral legislation establishing exclusive fisheries jurisdiction. This exclusive coastal state authority, except with respect to tuna, has clearly become customary international law. With regard to tuna, the United States neither claims nor recognizes exclusive jurisdiction beyond twelve miles from the coast. The United States will maintain its unwavering existing position on tuna fisheries.

\section{Marine Scientific Research}

The administration strongly supports freedom of marine scientific research. Research promotes the well-being of producing a better understanding of the effect of the oceans on the world's climate, more effective management programs for the world's living and nonliving resources, and more advanced pollution control measures. The LOS Convention grants discretion to coastal states to deny scientific research in their EEZ's and on the continental shelf. Nevertheless, the

7. 16 U.S.C. $\S 1801(1976)$. 
United States is confident it will be able to continue to conduct its marine scientific research without encumbrance. Bilateral and regional arrangements are possible wherever appropriate, and other less formal approaches to facilitating marine scienfitic research are under study.

D. Marine Environment

For the marine environment, the Convention is unnecessary. Existing international conventions provide adequate standards restricting the discharge of pollutants and regulating the design, construction, manning, and equipment of ships. The United States may enforce international standards as a precondition of entrance into our ports, a right recognized by international law. Present international law also permits a coastal state to assert jurisdiction to prevent or mitigate the threat of pollution damage caused by catastrophic accident. Therefore, existing international law can protect our interests in controlling marine pollution.

\section{Conclusion}

All the areas of oceans policy I have mentioned are important, and some are indeed critical to the United States' economy and security. The oceans policy we are developing will protect U.S. interests in each of these areas and will achieve the important and underlying goal of promoting deep seabed mining.

Critics of the administration contend that staying outside of the LOS Convention regime will only decrease the influence and power of the United States in global negotiations. But why has the United States enjoyed considerable influence and power in the past? Certainly not because, in its diplomatic initiatives, it so quickly abandoned those principles that have made it strong to begin with. Fortunately, those now responsible for our foreign policy are concerned with the application of our time-proven principles at home and abroad. The administration firmly believes that this is the proper approach, that only with such a position can the United States remain strong and cooperate effectively with our neighbors. As I recall President Reagan's remarking, "So often in history great causes have been won or lost at the last moment, because one side or the other lacked that last reserve of character and stamina, of faith and fortitude, to see the way through to success." 